\title{
O AMBIENTALISMO: AÇÃO E CIENTIFICIDADE EM DÚVIDA
}

Ambientalismo e Ecologia não são a mesma coisa. A Ecologia, do grego oikos, casa e logos, estudo, foi um termo inventado pelo zoólogo alemão Reiter, em 1885 para designar a ciência do habitat, ou o estudo das relações recíprocas entre os seres vivos e o meio ambiente. No início estava muito ligada a questōes de limnologia ou ciência dos lagos e aos modelos termodinâmicos e matemáticos, tendo evoluído até os mais modernos significados que recebe. Quanto à Ecologia não vemos maiores problemas de cientificidade, visto estar, normalmente, nas mãos de cientistas - a menos que, e isto é verificável em qualquer ciência, alguns conceitos nomades $^{1}$ nelas se ingiram sem a necessária filtração. Já Ambientalismo, que nem figura na maioria dos dicionários, vem a ser um amplo e variado movimento preservacionista que tem por objeto vários componentes do meio ambiente: fauna, flora, relevo, recursos hídricos, atmosfera, minorias como as indígenas, expoentes ou "satuários" da natureza - a biosfera enfim, ameaçada pelos sitemas produtivos vigentes. Uma de suas principais fontes de alimento é a Ecologia, mas não a única: indianismo, memória social, ética e outras frentes situam-se como importantes afluentes de idéias. O Ecologismo seria seu sinônimo; seus adeptos, os ecologistas diferentes de ecólogos, os cientistas da Ecologia. Apesar de muitos movimentos ambientalistas atuarem à margem das práticas político-partidárias, suas idelogias, como toda ideologias, acaba recaindo na política. É que muitos movimentos brasileiros que contaram com amplo apoio das bases, congregaram as mais diversas facções, tal o caso da Recuperação do Tietê, proposto desde o final dos anos 80 . É muito comum ainda, que um partido como o PV procure liderar as ações e que delas participem, igualmente, diversas facções. Há um subentendido que a preservação seria de benefício de todos.

O Ambientalismo vem se caracterizando em várias partes do mundo e no Brasil em particular, como sendo atributo de pessoas jovens. Aí ousamos formular um hipótese cuja demonstração não poderia caber num simples artigo, mas que fica de sugestão a quem quiser desenvolvê-la. Pensando na motivação do jovem de hoje, atormentado pelos estigmas de nossa era, supomos que ele queira fazer da terra não só o melhor dos habitats, mas o habitat definitivo. Os anos 60,70 e 80 conheceram uma crise de religiosidade que começa a se inverter nos anos 90. O Ambientalismo seria um substituto do sistema de explicação do Universo, o sentido mesmo da vida. Com base nesta premissa, o Ambientalismo passou a se associar a vários aspectos que estão na base da própria vida, tais como a busca de uma alimentação mais sadia; apologia de uma agricultura limpa de quaisquer agrotóxicos; busca de ervas medicinais e medicinas alternativas suaves como a acupuntura, homeopatia, aromaterapia, cromoterapia, musicoterapia, massagens... isto é, uma tendência a recusar a alopatia e seu modo, às vezes violentos; volta à natureza, onde os malefícios da cidade grande seriam menos percebidos (...); nostalgia de outros tempos, através da moda, da música, da memória social; busca de relação de respeito com a natureza e vários outros pontos que formam um sistema dito natural, de vivência, ainda que não esteja isento de escapismos. Estes pontos se posicionam com verdadeiro horror às práticas não conformes, a serem exorcizadas. Cabe ainda dizer que o movimento ambientalista é muito próprio das classes médias dos grandes centros urbanos, onde a presença frequente de várias formas de poluição e destruiçāo, facilita a mobilização, graças à informação e alguns segmentos das mídias. Não podemos prever se a volta à religiosidade, à partir dos indícios atuais, faria do Ambientalismo um movimento com características diferentes. Mas pode-se notar, na publicidade televisiva de algumas seitas e religiōes que tomam imenso vulto no Brasil, uma espécie de ironia em relação ao Ambientalismo. Lembram-nos, por exemplo, que há uma espécie em extinção, tâo

(*) Professor Doutor em Planejamento Urbano, no Departamento de Geografia da Universidade de Săo Paulo, e Professor Colaborador junto ao Curso de Pós-Graduação em Ciências Ambientais da mesma Universidade. Teve sua graduação, mestrado e doutorado pela Universidade de Paris.

(1) STENGERS, Isabelle (Dir.) - D'Une Science à l'Autre. Des concepts nomades. Paris, Seuil, 1987. 
ameaçada quanto os mico-leões dourados e que necessitam de igual carinho: as crianças abandonadas. Isto soa como boa bofetada num movimento que frequentemente insiste em desconsiderar a variável humana como principal componente da biosfera.

Como reconhecemos no Ambientalismo um fabuloso poder político, tememos que o excesso de motivação emocional, portanto com pouca base científica, seja capaz de enfraquecer várias conquistas de verdadeiro interesse social. É que ações pautadas em posições pouco fundamentadas podem levar a opinião pública à descrença na causa, ao cansaço do discurso. Não deixa de ser sem perigo, posto que disto tiram vantagens justamente aqueles que querem o progresso a qualquer custo, sendo cada vez mais comum ironizarem os ambientalistas como "eco-histéricos". Assim, pode-se perder batalhas devido a estratégias erradas. Esta característica emocional do Ambientalismo, diga-se en passant, é intenacional: verifica-se em países altamente desenvolvidos, mas no Brasil, por conta do baixíssimo índice de alfabetização e educação, assume proporçōes ainda maiores. A cientificidade não seria o único esteio faltante, mas aquele por onde se deveria iniciar uma ação mais consequente. A seguir, veremos pois, o que entendemos por método científico; por cientificidade duvidosa e finalmente, as possíveis saídas do impasse.

\section{O METODO CIENTÍFICO}

Seria falso afirmar que o método científico seja o único fundamento das mudanças. Historicamente, sabemos que grandes revoluçōes se processaram sem este recurso da intelectualidade e sabemos também, como admite a própria história das ciências, que a paixão é grande motivadora de criatividade, de invençőes científicas. No momento, há um dever ético e outro, dos modos de produção que exigem de nós postura de coerência científica, porque tem se afirmado fatos sem a menor comprovação, e deles se tem tirado caminhos a seguir. Seria de índole duvidosa seguir qualquer argumentação só porque. foram moldadas para reforçar nossos ideais de grupo. $\mathrm{O}$ nazismo de Hitler se baseou nas teorias de Gobineau (1816-1882), descritas em sua obra Ensaio sobre a desigualdade das raças humanas. Também não queremos afirmar que a política tenha de se- guir ipsis literis os ditames científicos, (que se exaurem em pouco tempo!) mas que estes representam algumas das referências de enorme peso: há incontáveis sistemas políticos que se impuseram antes mesmo de a Ciência se consagrar, à partir do Século XVI. A política poderia ter, por exemplo, preceitos unicamente humanísticos ou religiosos... O método científico se impõe, como um dos ingredientes, em nosso caso, como referência indispensável já que o discurso ambientalista consiste justamente em substituir o método dos outros pelo seu.

Neste breve artigo, falaremos de apenas alguns dos teóricos mais importantes na construção do método científico. Entre eles citaremos apenas Francis Bacon, Stwart Mill, David Hume, Karl Popper e mais recentemente, W.I.B. Beveridge. O primeiro grande teorizador foi Francis Bacon (1561-1626), um dos criadores do método experimental, explicitado no Instauratio Magna. Ele torna a pesquisa científica independente do princípio da autoridade e do método dedutivo. Ele estabelece uma classificação metódica das ciências e, no Novum Organum, de 1620, uma teoria da induçāo, que haveria de durar muito tempo. Para ele, era preciso coletar sistematicamente todas as informaçóes importantes do assunto pesquisado e em seguida tabulá-las. A conclusão, seria óbvia, mas caso não fosse, dever-se-ia então levantar um número de hipóteses de trabalho que seriam sucessivamente testadas, enquanto que se eliminava as inviáveis. Para Bacon entắo, a que sobrevivesse seria a verdadeira. Embora não seja esta a prática de hoje, este procedimento já representou um grande avanço para sua época. É que neste momento histórico, as interpretaçōes dos mais variados assuntos baseava-se ou nos clássicos da Antiguidade ou nas Sagradas Escrituras. Não pode ser esquecido que Bacon era advogado, Stwart Mill, David Hume e Karl Popper filósofos. Em outras, desconheciam o papel de vários fatores propulsores da descoberta científica não constantes do método, qual sejam, o insight imaginativo e o acaso ${ }^{2}$.

Seria falso afirmar que existe um método científico, modelo de operação para todos cientistas. Hoje em dia, admite-se com absoluta naturalidade que existe sim, uma pluralidade de métodos e mais ainda, que no fundo no fundo, cada qual constroi o seu. No entanto, é também sabido que há fortes denominadores comuns

(2) BEVERIDGE, W.I.B. - Seeds of Discovery. London, Heinemann Educational Books, 1980. 
entre os métodos usualmente aceitos por cientistas. Em 1974 , com a presença de 24 eminentes cientistas, incluindo quatro prêmios Nobel, teve lugar em Kronberg, Alemanha, o Simpósio de Processo Criativo na Ciência e na Medicina. Ele foi aberto por nada menos que Karl Popper, considerado o papa do método científico. Hoje em dia, segundo esta amostragem representativa de cientistas, o método se repousaria nos seguintes procedimentos:

a) Reconhecimento e formulação de um problema, onde, em qualquer ciência, se busca um fio condutor, ditado pela realidade ou pela imaginação. É nele que se desenvolverá o trabalho, em busca de soluções que representarão o avanço científico;

b) Coleta de dados, isto é, reunião de todas informaçöes pertinentes ao problema levantado, inclusive opiniōes em conflito, pois é deste confronto que, de vários pontos de vista diferentes se poderá abalizar o problema;

c) Formulação de uma hipótese por dedução, na qual se indicam as relações causais ou os padrōes significativos na informação levantada:

d) Elaboração de deduções da hipótese, momento em que se testa sua exatidão, seja pelo experimento ou pela coleta de mais dados;

e) Raciocínio de que se os resultados são coerentes com a dedução, a hipótese é reforçada mas não provada.

No entanto, W.I. Beveridge, autor de vários livros sobre a matéria, ele mesmo eminente pesquisador científico, tece críticas ao método hoje em dia comumente aceito, conforme obra citada. Para ele, as fórmulas são ilusórias, pois cada etapa se reveste de dificuldades lógicas e práticas. A formulação do problema pode estar errada, resultando num encaminhamento errôneo; a coleta de dados pode apresentar dificuldades, onde não sabemos distinguir quais informações são dados realmente relevantes; o raciocínio pela indução não apresenta grande segurança, sendo que alguns filósofos chegam mesmo a negar sua existência; na experimentação pode haver dificuldades práticas e possíveis fontes de erros; casualmente, os resultados serão quando muito, probalilísticos; podem ser enganosos, sugerindo mais de uma interpretação. Edward De Bono, autor de várias obras sobre criatividade, sugere que se utilizem artifícios que modifiquem a hipótese, como insumo alimentador de possíveis relaçōes.
Já para Karl Popper, o método científico se repousa nos seguintes procedimentos ${ }^{3}$. Ele não aceita a idéia de indução, pelo sistema hipotético-dedutivo. Deve-se sempre começar com uma hipótese, seja ela corrente ou imaginária. Aí então se raciocina do seguinte modo: se ela for verdadeira é seguida de várias deduçōes; planeja-se experimentaçôes ou séries de observações concebidas para negá-las. A hipótese é testada. Se os resultados mostrarem-se incompatíveis com a dedução, a hipótese é modificada ou rejeitada. No entanto, se eles forem coerentes, a hipótese é corroborada mas não aprovada. Em outras palavras, para Karl Popper a hipótese pode ser negada mas nāo provada. Hoje em dia, inúmeros cientistas seguem à risca os procedimentos de Popper.

Sobre este procedimento, Beveridge faz as seguintes críticas que consideramos muito oportunas. E que Popper não chega a dar maior ênfase à origem da hipótese, onde se encontra a alma da descoberta científica, e por isto mesmo é um poderoso instrumento de trabalho. Ele nega qualquer obrigação do ato criativo, reduzindo a questão do método a um procedimento quase mecânico. A fragilidade de sua filosofia reside no fato de que suas diligências em desaprovar a hipótese, isto é, desmontando teorias, é negativo. A História das Ciências mostra que na realidade, maior parte do tempo, os cientistas tentam chegar a um objetivo preciso e não ficar rejeitando a hipótese. Como exemplo, Beveridge lembra que antibióticos ou a estrutura do DNA não foram descobertos com negações da hipótese. Resulta então que deste tema central do poperismo, ou seja, a falsificação da hipótese, passa-se à idéia de que a única hipótese válida é aquela suscetível de teste e possível refutação. Trata-se de um procedimento efetivamente usado, mas temos de admitir exceções. Basta lembrar que muitas hipóteses não podem ser testadas. Como poderíamos testar o big bang, isto é, a explosão de um corpúsculo infinitamente pequeno que teria dado origem ao universo? Como poderíamos testar a evolução das espécies da qual Darwin se serviu? Como podemos testar inúmeras afirmações do Ambientalismo? Enquanto que a Engenharia Naval ou Aeronáutica podem construir maquetes, miniaturas de experimentação, como produzir uma maquete de ecologiacom todas as variáveis que intervém na natureza? Assim, em vários

(3) POPPER, Karl - Logic of Scientific Discovery. London, Hutchinson, 1972. 
campos do conhecimento, desde a Física e Química até as Ciências Humanas, há muitos fenômenos que não podem ser testados, pelo menos nas condiçōes que hoje dispomos.

Como ficamos então, $O$ que é o método científico? Se formos atentar a todas opiniōes, enveredaremos por um imenso cipoal... Só estamos autorizados a falar no método científico hoje, como uma pluralidade de procedimentos que tem alguns traços em comum, como segue:

a) Em primeiro lugar situa-se a necessidade de reconhecimento de um problema específico à área de trabalho, onde se destaca a importância da semântica para sua boa formulação;

b) Levantamento de informações pertinentes ao problema, onde se depara com a grande dificuldade de se saber quais dados são efetivamente importantes. Não existiriam assuntos pequenos, na medida em que se toma consciência, cada vez mais, de que tudo está relacionado com tudo, donde a importância do pensamento hierarquizado;

c) Formulação da hipótese, onde concorre a intuição, nem sempre consciente, gerada pelas informações de que se dispõe, donde a importância da criatividade;

d) Experimentação da hipótese, que vai necessariamente depender do ramo em que se trabalha, pois nem sempre pode ser testada;

e) Publicação, onde o conjunto das idéias elaboradas são expostos à coletividade científica; diz-se mesmo que ciência é conhecimento público. $\mathrm{O}$ tipo da publicação pode assumir as mais diversas formas clássicas e modernas: livros, artigos, filmes, vídeos, disquetes etc.

A compreensão sobre o exposto nos leva refletir sobre o tema deste artigo, a cientificidade dos movimentos ambientalistas. A militância nos tem demonstrado que suas ações sempre se baseiam em afirmações das mais diversas naturezas, supostamente colhidas da Ecologia ou nas variadas disciplinas que dizem respeito à biosfera: climatologia, botânica, zoologia, genética, química, nutrição... No entender do historiador das ciências, Michel Serres - professor da Universidade de ParisI, Pantheon Sorbonne e na Stanford University, há toda uma geração que ele qualifica de hemiplégica, em entrevista concedida a uma revista de grande circulação na França e que transcrevemos um trecho. "Muitos inte- lectuais de hoje são herdeiros diretos da geração precedente que foi formada pela linguística, etnologia, etc. Isto $e$, as ciências humanas ou, a parelha humanidadesciências humanas, mais exatamente. É uma geração à qual é preciso render homenagem, é claro. Mas, acrescentando que ela foi totalmente ignorante em uma outra vertente da modernidade cultural, que é científica: matemáticas, termodinâmica, física, química, genética e assim por diante. Por consequência, a reflexão política contemporânea é, freqüentemente, conduzida por pessoas que possuem uma cultura que eu chamaria hemiplégica. A pena é que as matérias digamos ambientalistas concernem a outra metade do conhecimento. Trata-se de abordar problemas de tipos físicos, climatológicos, estatísticos, bioquímicos, geofísicos etc". Conclui este pensamento dizendo "Ora, mesmo que eu diga isto só uma vez na vida, porque detesto polêmicas, creio profundamente que os intelectuais de ontem e os de hoje que são seus herdeiros, são delinitivamente desqualificados para falar destas questōes. A geração precedente falhou gravemente nos problemas que tocam a ligação ciência-sociedade" ${ }^{\prime 4}$. O próximo capítulo será uma abordagem que, mostrando algumas distorções, chama a atenção para a necessidade de maior rigor na fundamentação científica dos discursos ambientalistas.

Fica um problema no ar. Segundo ambientalistas, não é possível esperar o surgimento de evidências científicas sobre qualquer problema ambiental, porque seria tarde demais para atuar sobre ele. Esta posição nos remete a um outro problema. É que, em nome de algumas afirmações ambientalistas locais ou globais, vultuosos recursos financeiros são destinados. É urgente que se estabeleçam critérios muito bem disicutidos e que se estabeleçam as fronteiras entre uma fato presumível e outro possível. Não podemos aceitar que se aplique uma apagação deliberada sobre evidências científicas. Já chega o que a indústria da seca vem produzindo no Brasil. Isto também é uma questão ambiental legítima.

\section{A REFORMULAÇÃO DO DISCURSO AMBIENTALISTA}

Por razões já expostas na introdução, isto é, de revigorar a militância ecológica ou o Ambientalismo, será

(4) SERRES, Michel - "A mes contemporains, ces hémiplégiques...", in Le Nouvel Observateur, Paris, no 1435, pags. 24 e 25. 
preciso que este assuma alguns procedimentos, um deles, a cientificidade.

Seria ingênuo e mesmo falso admitir o Ambientalismo como corpo único onde se pode apontar um conjunto de características próprias e homogêneas a todos movimentos. A tentativa de sistematização do discurso descrito a seguir não deve pois ser vista como pertinente a um grupo, mas como resultado da observação traços perceptíveis e diluídas em diversos grupos, que podem ter várias destas características ou nenhuma. No entanto, supomos que do ponto de vista do grande público, o perfil do ambientalista seja percebido com estes uraços todos e outros ainda, uma forma de síntese da psique coletiva. É justamente isto que deve ser mudado à partir da reformulação do próprio discurso.

Conceitos. É bem provável que as maiores polêmicas surjam justamente no campo dos conceitos emitidos a propósito dos mais diferentes propósitos. Vejamos alguns, de ressonância internacional, extremamente repetidos em todas partes: o aumento da temperatura terrestre e do buraco de ozona.

Desde que o método científico se tornou prática, com mais intensidade à partir do Século XVII, a análise foi se acentuando como exigência do próprio método. Ou seja, era e é preciso separar uma parte da realidade para o estudo do mundo que vai do infra-atômico ao astronômico. Com análises e mais análises, o conhecimento foi se especializando cada vez mais, a ponto de hoje, por exemplo, cientistas não entenderem outros ramos de sua própria ciência. Na Matemática, cujo último grande matemático que a entendesse totalmente teria sido Poincaré, a ciência se ramificou tanto que hoje em dia é comum um matemático desconhecer um ramo da Matemática diferente do seu. O mesmo acontece com Física ou Química. Quando se deu conta que a biosfera atual é produto de incontáveis e quase indetectáveis ações humanas e não humanas, a Ecologia ressurge como disciplina de síntese, isto é, aquela que tendo por objeto a relação entre os seres vivos e o meio ambiente, seria a única capaz de explicar a biosfera na sua totalidade. Seria, em nossa opinião uma disciplina de síntese, na medida em que é a única que pretende entender o todo. A síntese, ao contrário da análise, visa rearticular as partes divididas. A Geografia, pela amplidão de seu objeto teria muito desta característica ou ainda, tende- ria a ter caráter muito ecológico. Ora, quando se afirma que o buraco de ozona tem mais características e tem por causa tais fatos, e que tal conceito é repetido com a maior facilidade por toda parte, nada impede o cientista rever o conceito em qualquer momento. Todos conceitos, inclusive os mais sagrados foram e devem ser objeto de revisão. Assim foi com a teoria de Einstein e tantos outros. Se houvesse verdades definitivas, nāo haveria progresso possível nas ciências. Por que os conceitos ecológicos não poderiam e deveriam ser revistos também?

É preciso ter em mente que hoje em dia o discurso ambientalista, que não é necessariamente o ecológico, pode influenciar eleições e por consequências políticas, legislações, normatizações do sistema produtivo etc. $\mathrm{O}$ movimento dos verdes vem adquirindo enorme peso na Europa, onde a Alemanha lidera em importância política; na América do Norte, os Estados Unidos vem o peso de sua importância aumentar ano a ano, graças às inúmeras ONGs atuantes, sustentadas com contribuições particulares. Vários membros do primeiro escalão da Casa Branca sāo egressos de Associações Ambientalistas. Face a este poder de influenciar políticas, é justamente por isto que a argumentação ambientalista, consciente, como pretendemos, deve reguardar-se do decrédito. Não só tem de municiar-se de cientificidade como, com diligência, não sirva de pretexto a enganaçōes do inimigo político.

Diz-se que o buraco na camada de ozona está aumentando e que isto teria consequências desastrosas para a humanidade, como a propagação do câncer de pele, já que os raios solares nocivos não seriam filtrados. Como militantes do Ambientalismo congregam variaçōes que vão da dona de casa ao estudante $e$ intelectual de universidade, é muito comum não termos elementos suficientes para poder julgar um conceito e assim aceitamos e repetimos chavōes. Dito claramente, nảo estamos isentos do boato ecológico. Seria mesmo muito interessante estudar a origem de algumas afirmaçöes muito repetidas. No Brasil se repete muito que a ONU estabelece para os centros urbanos, um mínimo de $16 \mathrm{~m}^{2}$ de áreas verdes por habitantes; já ouvimos também o índice de $12 \mathrm{~m}^{2}$ apenas. Em colóquios com funcionários da ONU, ouvimos que até então a Onu jamais estabelecera este patamar, que talvez tenha sido a opinião pessoal de alguém da ONU que visitou o Brasil 
há duas décadas... A hipótese do buraco da camada de ozona pode ter tido origem semelhante, como ainda pode ter sido uma hipótese concebida com a maior honestidade, porém sem fundamento. Estávamos mesmo propensos a ceitá-la como definitiva, não fosse depararmos com um estudo do Professor Milton Santos, talvez a maior autoridade mundial viva, em Geografia. Este ilustre professor da Universidade de São Paulo, Doutor Honoris Causa pela Universidade de Buenos Aires, com passagens pelas melhores universidade do mundo nos chama a atenção para algumas deturpações do conhecimento ecológico, quanto ao aumento da temperatura terrestre ${ }^{5}$.

Milton Santos cita B. Kayser "Sobre o aquecimento da terra e o efeito estufa. Pode-se estar certo de que, apesar do contínuo crescimento do teor em $\mathrm{CO} 2$ da atmosfera desde o começo da era industrial, o clima não conheceu aquecimento no século 20 . As normais medidas entre 1951 e 1980 , em relação às do período 1921-1950 mostram, ao contrário, uma baixa (não significativa) de $0,3^{\circ}$. De qualquer modo, a evolução é muito lenta, e dezenas de anos são necessários para que se registre uma mudança climática. $\mathrm{O}$ apocalipse anunciado - fusão de glaciares, elevação do nível do mar etc. - não é seguramente para amanhã. Se é necessário lutar contra a poluição, a degradação do meio ambiente, devemos fazê-lo com os olhos abertos, com base em análises científicas e não nos limitando a gritar: 'está pegando fogo".

Publicações recentes apresentam teorias contrárias ao entendimento comum sobre o chamado buraco da camada de ozona. Enquanto uns propagam seus terríveis perigos, outros cientistas, inversamente, consideram-no indispensável à vida! É com preocupações semelhantes a esta que Milton Santos se expressa na mesma obra citada: "Estaremos de volta ao 'mundo mágico', onde o fantasioso, o fantástico, o fantasmagórico, prometem tomar o lugar do que é lógico e o engano pode se apresentar como o verdadeiro?", concluindo que "É a mídia o grande veículo desse processo ameaçador da integridade dos homens. Virtualmente possível, pelo uso adequado de tantos e tão sofisticados. recursos técnicos, a percepção, é mutilada, quando a mídia julga necessário, através do sensacional e do medo, captar a atenção. Muitos movimentos ecológicos, cevados pela mídia, destroem, mutilam ou reprimem a Natureza..."
Ação. Não falamos aqui da ação ou aplicação da Ecologia, que como quase todas ciências tem seu lado prático. Referimo-nos à ação do Ambientalismo, nos termos acima definidos. Ela vem assumindo tal forma que por associação de idéias, quase não há quem não associe à juventude. As mídias sāo férteis no estabelecimento deste parentesco, contribuindo para desvirtuar aquilo que poderia ser um Ambientalismo alimentado pelo saber científico. E então, assistimos a um turismo dito "ecológico", onde o fundamental é ser jovem. Jovem para se descer a correnteza dos rios em pneus; para se escalar escarpas íngremes e andar sobre pedras; para percorrer trilhas no meio da floresta tropical, acampando e comendo o que der; para se tomar banhos de cachoeiras; para se desembarcar em encostas bravas com bom equilíbrio e assim por diante, onde o fundamental é ser teenager ou pouco mais. O Ambientalismo foi reduzido a uma questão de jovens. O "resto" parece assistir a tais proezas com muita resignação, como se a sobrevivência na biosfera fosse mesmo uma questão etária. A Ecologia então, que tem uma das mais nobres missões, isto é, de moldar um mundo onde tudo estaria em constante busca de equilíbrio, vê o Ambientalismo eliminar a participação, indispensável, de todos. De resto, a própria forma como a sociedade está organizada, na qual embarcam os ambientalistas, é propícia a este tipo de descriminação. Justamente agora em que cresce a população de idade mais avançada, que poderia ser extremamente útil para si mesma e para os outros dedicando seu tempo ocioso à questôes semelhantes a esta. O pior ainda é que o movimento ambientalista, estabelecendo um certo perfil do que seja o ambientalista, freqüentemente desvia-o da mais fecunda das ações, a política. O turismo ambientalista tem o cheiro de São Tomé das Letras, da Chapada dos Guimarães, de Trancoso e nem um pouco das Praias Grandes da vida. Não é que se tenha de optar por um ou outro, mas por ambos! Ao descer o rio de pneus, ao usar uma "camiseta ecológica", ou cantar e dançar músicas de igual preocupação, acabamos pensando que cumprimos nossa missão conscientemente! É justamente isto que o esquema de dominação quer. Então, turismo ecológico é simples-

(5) SANTOS, Milton - 1992. A Redescoberta da Natureza. Universidade de Săo Paulo, Faculdade de Filosofia, Letras e Ciências Humanas, 1992.

(6) KAISER, Bernard - Pour une analyse non conformiste de notre societé, intervention à l'URN de Cologne (25.01.92), Univ. de Toulouse, fév. 1992, mimeografado. 
mente perambular pela natureza e não, por exemplo, brigar por leis de uso e ocupação do solo em todos locais turísticos que tomam conta deste bonito Brasil. Leis que estabeleçam com rigor índices de permeabilização do solo; de taxas máximas de ocupação, de usos compativeis com os princípios ecológicos; de preservação da memória social na conservação dos conjuntos urbanos representativos de nossa cultura e assim por diante. Açōes que protejam as frágeis populações caiçaras ou caboclas ou indígenas. Aí, é preciso que novamente se processe a revisão dos critérios de demarcação de terras, exigindo que se proporcione ao caiçara ou caboclo um quinhão justo, pois perante a Lei e Deus, se preferirem, somos todos iguais. Aí é preciso também que se tomem precauções complementares porque a Amazônia vem sendo cobiçada mais e mais e sempre foi do interesse internacional que permanece com a menor população possível...

Com freqüência cada vez maior vemos lançaremse os ditos "loteamentos ecológicos", assim denominados porque descobriu-se que se vende mais produzindo este tipo de apelo. Ser "ecológico" é ser rico e bem nascido... O loteamento é visto com significado autộnomo, isto é, independente do perfil do usuário, que dentro obdece às regras do condomínio e fora polui o que puder com seu sistema produtivo. Estes loteamentos estão nos grandes centros, nas praias quase desertas, como guetos protetores das elites que assim tem como se livrarem das hordas; onde a ação ecológica se consuma intramuros.

Construir nosso futuro segundo nossas crenças é um direito civil e reconhecido até pelo chamado livre arbítrio religioso. Como sempre, nos esbarramos no problema apresentado pelos mitos, com o risco de embarcarmos no inverso do que pretendemos. A idéia de natureza e de seu papel atravessam o tempo e o espaço com enormes variações de interpretações. Falando de Ambientalismo, era inevitável que falássemos um pouco da utopia naturista. Isto tem sido objeto das discussões no mundo inteiro. Nossa dependência da natureza é inevitável porquanto sejamos animais. É mesmo definitiva, porque mesmo que pudéssemos viver numa nave espacial, esta nave estaria em algum ponto do Universo, onde a natureza é diferente mas é sempre natureza. $\mathrm{O}$ problema é que a utopia naturista surge como substituta do terceiromundismo ou ainda como álibi do tradicionalismo religioso. Sobre isto há um inteligente livro de
Grenier ${ }^{7}$. Ele nos parece oportuno porque traz a discussão de temas muito atuais. A obra, consagrada ao estudo de Tchekhov (1860-1904), que como se sabe, consagrou-se a escrever sobre a vida medíocre e absurda dos senhores do campo, ou como dizemos entre nós, da aristocracia rural. Relata a história do filho de um senhor próspero que deseja realizar o sonho de chegar à intimidade do povo, conforme princípios pregados por Tolstoi. Ele finge então ser operário, vê seus projetos resultarem em fracasso. O conflito se patenteia porque, casado com uma senhora da sociedade, vê que esta simplesmente detesta a sujeira e a vulgaridade dos cidadãos comuns que ela se via obrigada a receber em sua casa. O autor diz entāo: "A moral de Tolstoi que vira as costas ao progresso provoca horror no neto do servo que nada vê de admirável na volta à vida interiorana". Tchekhov responde então: "Do mais fundo de meu coração, não tenho simpatia pela moral de Tolstoi. Em mim corre uma sangue de mujik e jamais se me encherá de admiração com as virtudes do mujik. Desde minha infância, acreditei no progresso e não podia deixar de crer porque a diferença entre a época em que me chicoteavam e a época em que se cessou de faze-lo foi extrema... A razão e a justiça me dizem que há mais amor pelo homem na eletricidade e no vapor que na continência e na abstinência de carnes. A guerra é um mal, mal o fato de julgar é um mal, mas não é uma razão para que eu use sapatos de mulher ou que eu durma sobre o aquecedor com meu empregado e sua mulher". Grenier conclui: "Para mim o campo sendo a pior das punições que eu possa imaginar, fico feliz de que no fim do Século XIX o homem tenha acertado as contas com a retrógrada idéia de volta à terra, que sempre serviu de arma ao que há de mais reacionário, do regime petanista aos modernos ecologistas. Voltar ao campo, é fazer injúria a nossos ancestrais que levaram tantos séculos para se libertarem da terra pegajosa e de seu trabalho escravo".

À partir destas citações literárias, em que a liberdade e a franqueza do discurso do artista nos ajudam a reciocinar, constatamos que o conceito de Ambientalismo vincula-se a uma ideologia retrógrada, reacionária, se estiver associado à uma idéia de pureza original da natureza e de purificação do planejamento da humanidade. $\mathrm{O}$ mito do bom selvagem se desmoronou deixan-

(7) GRENIER, Roger - Regardez la Neige qui tombe - Impressions de Tchehov. Paris, Gallimard, 1992. 
do substitutos. Mas o mesmo conceito ecologista pode também ser totalitário se alimentar um projeto de sociedade que tenha como único objetivo a correção do progresso tecnológico. $\mathrm{O}$ mundo se tornou uma grande aldeia, onde as interações atuais se processam mais e mais. Hoje em dia, o destino do planeta tornou-se indissociável dos que nele habitam. É esta variável humana que tem de ser resgatada nos movimentos ambientalistas e que não pode ter como única motivação a emoção.

A Educação Ambiental. Este é um tópico que necessita de uma delicadeza de ouvires para ser bem entendido, pois tem de ser colocado no contexto de uma nuança precisa. Uma das questöes que queremos chamar a atenção diz respeito ao peso que deveria ter a educação ambiental, outro a seu próprio conteúdo.

Quer parecer-nos que os governos estimulam demasiadamente a questão da educação ambiental justamente para insentarem-se de compromissos que não ousam enfrentar. Em duas palavras, é mais cômodo ficar sustentando a educação ambiental frente ao público, já que é relativamente inócua para o sistema a curto prazo, do que enfrentar o verdadeiro cerne da questão, que seria sentar-se com os empresários e rediscutir os modos de produção. Não é pois que a educação ambiental seja indesejável, mas que superestimá-la em detrimento de outras frentes de atuação pode ser nocivo para a própria causa desta educação. Ademais, a educação é basicamente destinada a crianças, onde os resultados mais férteis se veriam naquilo que "sobrar" de tais agentes humanos, vista a crescente fuga escolar. Neste futuro, poucos, efetivamente ocupariam postos em que a educação provocasse os efeitos positivos. Quer-nos parecer que a educação ambiental, sem deixar de preocupar-se com as crianças, deva infiltrar-se justamente nas áreas de atuação de toda classe de administradores de territórios e da vida pública, ministros, governadores, prefeitos, deputados, vereadores... Estes sim precisam ser educados e com urgência. Mas talvez já conheçam a lição e por isso mesmo queiram dela fugir. Donde, a educação, enquanto processo, teria de converter em posturas que passam pelo Legislativo e se tornem parâmetros de atuação daqueles que verdadeiramente interyem na bisfera.

O Brasil tem assistido a um esforço muito sério de educadores empenhados na salvação do planeta. A cada seminário vimos surgir uma quantidade muito grande de cartilhas, cujos teores sāo tão variados quanto seus autores. Muitas pecam pelo maniqueísmo, poucas primam pelo conhecimento da realidade no devido ponto. Há, nos parece, um exagero de preocupaçōes de caráter comportamental "civilizado", anti-séptico, em detrimento dos aspectos realmente relevantes daquilo que poderia ser o Ambientalismo, Equivale dizer que há um vazio imperdoável, representado pela insistência da ignorância das duas questōes realmente importantes no Ambientalismo: os modos de produção e o crescimento demográfico. São duas vertentes da mesma preocupação. Todo o mais perde em importância face a estes fatores. No entanto, desconhecemos qualquer texto de educação ambiental preocupado em induzir crianças (ou adultos) a serem menos consumistas; a serem alertados sobre os inconvenientes da super população: cada um, em sua escala, contribui para o agravamento destas questōes. A focalização destes dois problemas teria de levar em conta o público específico: uns nem sequer chegam a consumir por total carência de recursos; outros não se proliferam tanto justamente por serem mais bem situados socialmente. Todavia, nem com estes senões o consumismo e fertilidade podem ser descartados. Estes pontos nos parecem da maior relevância e são ùm toque para nos acordar: não podemos continuar nos iludindo (e iludindo os outros) que estamos produzindo uma boa educação ambiental.

Nas narrativas usuais, há ainda uma tendência em se construir um tipo humano, um campo, uma cidade enfim "ecológicos" sem muita preocupação em mostrar a complexidade e heterogeneidade da vida. Ao invés de alguns personagens ambientalistas e meio utópicos, preferimos figuras do tipo de uma certa Joan Lowel. Esta senhora americana existiu, morou muito tempo no Brasil e acabou escrevendo um livro chamado "Terra Prometida", traduzido para o português pela Melhoramentos. Joan foi viver no sertão de Itanhaém, Estado de São Paulo, e nas lonjuras de Goiás, nos idos dos anos 30 , quando aquilo era realmente só sertão. Suas considerações são cheias de abordagens ecológicas no melhor sentido. Ela fica espantada como a natureza coloca as coisas exatamente no lugar em que se precisa delas. Cita vários exemplos ao longo do livro. É assim que num terreno pedregoso, onde as pessoas facilmente caem e se machucam, medra, milagrosamente, uma erva "destinada" a contusões... Mas como se percebe pela biografia da autora, ela não deixa de ter graves falhas ou contradições de caráter, inclusive ambientalistas. Ela 
é nossa própria contradição interna, o espelho da realidade e não um ente inalcançável. Esta questão do modelo na educaçāo ambiental mereceria ser revista no sentido de situar a dinâmica de um mundo complexo e mutante. Estas colocaçōes, se admitidas pelos educadores e mais ainda pelos que traçam políticas de educação, teriam de ampliar o horizonte de posturas comportamentais de cidadão educado, de natureza humanizada à la Walt Disney para engajamento efetivo do cidadão no processo.

Não deixa de ser chocante o modo como se vê o povo entender algumas mensagens do pensamento ecológico. Os jornais e revistas comuns estão repletos de conceitos absurdos como "destruir a ecologia". Ecologia se converte em sinônimo de natureza em detrimento da idéia principal que é o da relação recíproca entre os seres vivos e o meio. Fala-se de uma casa, uma praia, um loteamento "ecológicos", simplesmente porque se nota alguma natureza no entorno (para eles, qualquer...) e não porque são concebidos como formas inteligentes de uso da natureza, estas, freqüentemente, perdendo seu sentido. Parecem não se dar conta de que absolutamente tudo é ecológico, inclusive uma explosão nuclear, porque se trata do estudo da relação e não de uma perfeição, de um equilíbrio estático. Terá de se inventar outro substantivo para esta idéia subjacente de ideal, pois "ecologia" foi inventada para outros significados. A linguagem das mídias é também profícua, tanto quanto o povo que repete, de dizer que tal alimento ou tal remédios são bons porque não contém "químicas", como se fossem produzidos por substancias etéreas. A educação ambiental no Brasil, competiria acertos científicos que levassem em conta uma realidade onde o acesso a bens erroneamente chamados de "ecológicos" são atributos das elites. Qual seria então o papel das massas famintas senão o de reconhecer que a miséria é a pior poluição e disto as elites se conscientizarem?

Alimentação e saúde. Finalizando uma série de características do militante do Ambientalismo, vemos um conjunto muito grande de hábitos alimentares e de cuidados com o corpo que não são isentos da idéia de purificação, de salvação contra um mundo de violências de todas espécies. A alimentação e os cuidados dispensados ao corpo enquanto terapias não deixam de ter seus mitos, seus desvios científicos.
Não há quem duvide que uma alimentação isenta de agrotóxicos ou de hormônio artificiais de crescimento seja boa para a saúde. No entanto, não se pode negar o trabalho de pesquisadores que no seio da Universidade e dos Institutos de pesquisa vem buscando a produção de pesticidas de toxicidade nula. Isto já foi comprovado em laboratório e não há razão, com o mesmo grau de cientificidade, capaz de negar. Enganam-se os que pensam existir apenas dois extremos - os alimentos absolutamente puros, sem pesticida e os contaminados, com pesticida. Seria ideal que sequer se usasse pesticidas com toxicidade nula. Mas não é possível pensar na alimentação do mundo com seus cinco bilhões de habitantes por meios tradicionais de agricultura. Muitas teorias políticas vem apregoando que este tipo de agricultura é possível, que não é necessário controlar a natalidade... Decorridas décadas, esta posição em nada solucionou os problemas da fome. Já não se trata de saber se há agrotóxico nos alimentos mas se há alimento! Apenas os que já estão bem alimentados se preocupam com os modos de alimentação. Seriam coerentes se, já que tem tanto amor ao próximo, que dispensassem a mesma energia na distribuição da riqueza, no aumento do salário mínimo para o mínimo 500 dólares. Sim, porque um salário de 60 U\$ no Brasil e o triplo na Argentina e México vem dar exatamente na mesma coisa, considerado o custo de vida nesses países. É preciso dinheiro para comer produto natural, é preciso muito dinheiro para praticar uma agricultura sem pesticidas.

O Ambientalismo é coerente ao buscar produtos integrais para a alimentação humana. Só que, esquecese que no Brasil o grão integral muitas vezes chega a ser mais nocivo que o grão não integral. Alguém acredita que o Brasil pratique uma agricultura sem agrotóxicos? Alguem duvida que o agrotóxico aspergido não se concentre justamente nas camadas exteriores dos grãos? Não só naufragamos na ilusão de estar comendo melhor como, suplementarmente, não ingerimos o grão como é preciso. Melhor explicando, a Fundação Kousmine de Paris, dirigida pela médica russa que lhe deu o nome, já provou que a alimentaçāo natural ("La Méthode Kousmine") tem pouco a ver com o que supostamente se chama de "natural". Todos os grãos, explica, para não perderem suas principais propriedades, tem de ser "fraichement moulus", isto é, moídos, praticamente, na hora do consumo. Certas vitaminas (" $\mathrm{H}$ ") só subsistem nestas condições. Óleo, preferencialmente de oliva, desde que de primeira pressão e prensado a frio, e ainda, conservado em geladeira após abertura da lata. Atual- 
mente, a França importa este produto da Suiça, porque só lá existe perfeito controle de qualidade. Estas normas e várias outras, comprovadamente certas, tornam o usuário meio escravizado da alimentação, razão pela qual muitos médicos só conseguem recomendá-la em situaçöes de terapia específica. Em duas palavras, a alimentação natural teria de ser assim e uma vida dita natural teria outras implicações. Em Paris, onde existem algumas feiras de "produits bilogiques", que é como os francêses chamam os produtos naturais, a principal delas ocorre no Boulevard Raspail. O preço de qualquer verdura, legume ou fruta equivale ao dobro ou triplo do normal, e não podem ser avaliados pelas condições externas, isto é, a aparência é sempre menos vistosa, alem de serem de tamanho menores que os tipos encontrados normalmente no comércio. Desde longa data, muitos países da Europa expõem dois tipos de aves: com hormônios, mais baratos, e sem hormônios , quase o dobro. $\mathrm{O}$ Brasil ainda não acordou para este tipo de diferenciação. Há outro tipo de equívoco que, embora menor, cabe ser citado por ilustrar a mesma ideologia não científica tocante à "vida natural". Muitos produtos como o iogurte ou mel ou açúcar mascavo vem sendo veiculados pelo comércio como contendo propriedades deificantes. É certo que o mascavo é melhor que o açúcar refinado, mas não deixa de ser nocivo. Considerada a classe A do mundo inteiro, a do Brasil é uma das que possuem o pior índice de qualidade dentária. A Escola de Nutriçãa da Universidade de São Paulo vem se pronunciando com oportunos artigos de seus professores e pesquisadores chegando a desmistificar um certo tipo de chamada alimentação natural. Esses produtos podem ser melhores, mas não chegam a possuir virtudes do Olimpo: tem mais minerais, vitaminas, engordam e em muitos deles não se verificam as apregoadas virtudes terapêuticas. Há uma mistificação generalizada nas virtudes dos produtos, estimulada pelo comércio dos fabricantes, onde poucos laboratórios possuem credibilidade internacional no tocante à composição, fabricação; embalagem, estocagem... Chegamos a ver um curso na televisão onde se ensinava que a alimentação natural tinha de ser obrigatoriamente em panelas de barro e de preferência, barro do Rio Jequitinhonha(!). Do mesmo modo, uma gama imensa de chamados "produtos caseiros" chega a ser inferior a seus similares industrializados: além de se servirem de ingre- dientes de origem duvidosa, não se submetem a qualquer controle de qualidade e, alem do mais, podem ser ter sido fabricados em condiçōes de absoluta falta de higiene. Descobriu-se que se vendem e isto basta a qualquer comerciante, incluindo os chamados "sanduíches naturais".

A questão da distribuição e qualidade de alimentos continua a ser escandalosa em quase todo o mundo, pois, como todas questōes, está ligada ao exercício consciente da cidadania, o que não ocorre em toda parte. Há muito o que se modificar, mas é incontestável, também, que jamais antes se alcançou uma esperança de vida e um padrão alimentar tão altos a ponto de mudar o biotipo do homem. Jamais antes se conseguiu tantas safras. A distribuição dos alimentos é uma vertente do mesmo problema. Esta-se revelando em pesquisa conduzida pela Professora Maria Adélia A. de Souza, no Departamento de Geografia da USP, que fome e pobreza não são a mesma coisa - um é condição biológica e outra, política. Segundo este grupo, é justamente nos países exportadores de alimentos que há mais fome e que, enquanto no Brasil a fome segue seu curso "normal", em países do Primeiro Mundo ela cresce entre $2 \mathrm{e}$ $3 \%$ acima da curva tradicional.

$\mathrm{Na}$ medicina vem se verificando um crescimento salutar de terapias alternativas (homeopatia, acupuntura, florais de Bach...) que pelo simples fato de não violarem ou violarem menos o organismo humano, já são aconselháveis em muitos casos. Mas não todos, onde o mesmo preconceito contra alimentos industrializados, mesmo que bons, leva à recusa de cirurgias ou alopatias. Em certos casos, no entender de muitos médicos naturalistas, o ideal é combinar todo o bom senso e conhecimento científico disponível, sob o risco de criar problemas. $\mathrm{O}$ adepto de uma idéia é freqüentemente mais radical que a própria idéia. Paradoxalmente, nem tudo o que é natural faz bem, aí estẩo todos venenos e toxicidades naturais a nos provar. A opinião médica está dividida mesmo porque os próprios médicos estão tão sujeitos quanto nós a mistificações. Aliás, a Organização Mundial da Saúde em Genebra, proclama abertamente que onde não há médicos que se procurem curandeiros. A questão da cura é um campo onde ainda só havendo conclusões muito parciais, é preciso precaução na escolha dos caminho a serem seguidos. portanto, precauçāo com as ideologias. 
Pessoalmente, temos nítida preferência por políticas agrárias isentas o mais possível de agrotóxicos. So que, esta ambição, como todas, tem de começar pela luta política, pois está-se questionando, nada menos do que o Modelo Ocidental de desenvolvimento capitalista. É preciso que sejamos coerentes, isto é, usar a estratégia certa para alcançar determinado fim.

\section{NOVOS RUMOS}

Possuimos um entendimento sobre o que devam ser associaçōes ambientalistas, de modo bem adverso do usual. Entendêmo-las como verdadeiras guardiãs da sociedade, o que, necessariamente altera seu organograma funcional. É muito comum vê-las conduzindo pequenas pesquisas, pequenas por que dada a estrutura limitada de investimentos que possuem, não conseguem alinhar muitas frentes de conhecimento científico, como requer a salvaguarda do mundo. Defensores do lema "ou se estuda ou se governa", optamos por atribuir à Universidade e aos Institutos de pesquisa a tarefa da investigação. Este vem sendo o papel tradicional destas instituiçōes, sendo bem poucos os acréscimos que as associações ambientalistas tem feito. Elas simplesmente não conseguem enfrentar esta "concorrência". É preciso que se lembre também que a Universidade está cheia de ambientalistas e bons. Com isto queremos dizer que o papel fundamental das associações ambientalistas não seria o de fazer pesquisas mas de estar extremamente atenta, vigiando o governo e o empresariado. Alimentando-se na própria Universidade e nos Institutos, de onde podem até encomendar pesquisas e contar com a simpatia deles, consagrariam seus esforços na ponte, muito tênue, entre Universidade e Sociedade. Aliás, diga-se de passagem, é momento de os próprios cientistas saírem mais para as ruas. Assim, fortalecida pelo conhecimento científico fundamentado, sua ação seria inevitavelmente mais forte, porque à ciência se soma a política. Infelizmente muitas de nossas associações, alimentadas por contribuintes brasileiros e estrangeiros, legitimam o emprego do dinheiro no alimento de um corpo de pesquisa permanente. É muito pouco como resultado, embora algumas já tenham alcançado grandes efeitos por terem contado com a simpatia das mídias. Cremos que no máximo, deveriam se preocupar com metodologias, o que implica em contarem com membros altamento qualificados do ponto de vista pro- fissional. Isto vem sendo nossa preocupação desde meados da década de 80 , quando idelizamos um projeto que não chegou a se concretizar, que seria uma Fundação de Cultura e Ecologia, sediâda no Puruba, Ubatuba, Estado de São Paulo. Lá haveria um Forum de Debates, cujos subsídios científicos seriam encomendados pela população local à Fundação. Esta contrataria os especialistas conforme a natureza do problema ambiental que estivesse preocupando a população. É com base nessas discussões que se iria subsidiar a luta política dos requerentes. É preciso pesquisa, muita pesquisa para elucidar o meio em que vivemos e suas tranformaçōes, cuja bibliografia é irrisória face ao que o Primeiro Mundo dispõem sobre eles mesmos, e em muitos casos até sobre nós. É preciso intervir no Orçamento Geral do país e rever a distribuição da verba.

Os meios de comunicação seriam outra vertente não menos importante, já que são os verdadeiros fazedores-de-cabeça. Ao invés de jornalistas em generalidades e divulgadores de vícios, teríamos de contar com entendedores da matéria, que de início, teriam de sanar todos vícios de conceito que se propagam e deformam o entendimento da questão. Cada problema teria de ser levado com absoluta maestria, o que não impede de ter por patamar uma linguagem entendível pelo grande público. Teria, acima de tudo, uma responsabilidade ética pelas matérias tratadas. Neste mesmo raciocínio, somos por um aprimoramento da educação ambiental de todo tipo que se veicula, especialmente a de caráter oficial. E mais, que seja dirigida não só a crianças e adolescentes em formação como aos agenciadores do espaço (governo dos três níveis, empreendedores imbiliários etc) aos produtores de bens de consumo de toda espécie. Não se pode continuar opondo preservação a desenvolvimento. É o conceito de desenvolvimento que tem de ser modificado naquele sentido de que só há verdadeiro desenvolvimento com a preservação. Pode-se mesmo pensar que, com boa fundamentação científica, as próprias leis pertinentes deveriam estabelecer parâmetros de atuação.

Do ponto de vista político, cremos que o Partido Verde tenha uma missão histórica a cumprir porque o engajamento dos outros partidos nesta questão ainda deixa muito a desejar. No entanto, admitimos que se o Partido Verde conseguir se manter como tal no futuro, a questão ecológica terá de se diluir em todos partidos, os quais deveriam tender a refletir, mais incisivamente, 
como tratam a questão. Se a questão da vida na biosfera é uma questão que afeta todos segmentos da organização do país não vemos porque deva ser tratada como uma categoria separada. Era como se precissássemos de um partido para a fome, outro para o negro e assim por diante. O Ambientalismo, por envolver questổes extremamente sérias da atualidade teria de contar não com um ou dois, mas com dezenas de deputados federais e estaduais, com centenas ou milhares de vereadores que "comprassem" a questão. É pelo menos, o que um suposto equilíbrio de forças políticas requer.

Como palavras finais e incisivas, diria que o ambientalista deveria investir mais e mais em sua formação, num processo sem fim de alimentação de boas informações, porque o mundo está em mudança acelerada. Como sua atuação não é a da rotina comum, aumenta sua responsabilidade enquanto comunicador e militante. Como donos deste discurso escrito, não queremos que se entenda ser a ciência a única salvação do
Ambientalismo, mas que ela é um dado fundamental para ele; que ela sozinha é como uma andorinha que não faz verão. Tem de ser somada à Política e bem antes à Ética, porque ciência sem Ética é melhor que não exista. Entretanto, apesar dos desvios do Ambientalismo que percebemos, não deixamos de ver com muita simpatia a motivação de todo movimento. A questão tem outro reverso, que Carlos Drummond soube muito bem exprimir em duas poesias-prosas. Primeiro ele diz que "não adianta o velho ganhar a discussão, a vida fica com o jovem". Em outro escrito ele declara que "Revolução se faz na raça" 8 .

Esta comunicaçāo foi especialmente preparada para TECENDO UM NOVO OLHAR, Forum de Debates sobre Educação e Meio Ambiente, da Universidade de Brasília, em sessũo de 06 de novembro de 1993.
(8) ANDRADE, Carios Drummond de - O Poder Ultra Jovem. São Paulo, Editora José Olympio, 1973. 